\title{
Desmoplastic Spitz nevus
}

\section{Vladimír Bartoš}

\author{
Martin's Biopsy Center, Ltd., Martin, Slovakia
}

Corresponding author: Dr. Vladimír Bartoš, PhD., E-mail: vladim.bartos@gmail.com

\begin{abstract}
Desmoplastic Spitz nevus (DSN) is an uncommon variant of melanocytic nevus rarely encountered in dermatological practice. Herein, we describe a 54-year-old male who presented himself with a cutaneous tumor arising from the left arm. Histology revealed an intradermal proliferation of somewhat pleomorphic, epithelioid, spindled melanocytes in a background of desmoplastic stroma. A perineural invasion of tumor cells was found. Proliferative and mitotic rates were minimal. The tumor was diffusely positive for S-100 protein, PNL-2, and SOX-10, and only occasionally reactive for melan-A and HMB-45. The final diagnosis of DSN was established. Although DSN is a completely benign tumor, it may result in diagnostic pitfalls. Due to its unusual histopathological features, it may be confused with a malignant desmoplastic melanoma. A knowledge of the clinicopathological differences between the two prognostically distinct skin tumor entities is essential for a differential diagnosis.
\end{abstract}

Key words: Desmoplastic Spitz nevus; Desmoplastic malignant melanoma; Perineural invasion

\section{INTRODUCTION}

Desmoplastic Spitz nevus (DSN) is an uncommon variant of melanocytic nevus characterized by dermal proliferation of large epithelioid or fusiform melanocytes in a sclerotic stroma [1-5]. It occurs more frequently on the limbs of young adults, predominantly females, in the third decade of life [1-4]. Compared to the classical variants of melanocytic Spitz nevi [6], DSN exhibits some distinct microscopic features, such as the lack of dermoepidermal activity, the absence of Kamino bodies, the presence of ganglion-like epithelioid cells, and increased collagen bundles in the dermis [1-5]. From a practical point of view, DSN is particularly important as it may be confused with a desmoplastic melanoma [1-5]. Therefore, in routine biopsy practice, such cases may be diagnostically challenging. Herein, a case of a patient with DSN is described from a pathologist's perspective.

\section{CASE REPORT}

A 54-year-old male was found to have a cutaneous tumor lesion arising from the left arm. Grossly, it appeared as a light-brown, well-circumscribed, elevated nodule $6 \mathrm{~mm}$ in size. The presumptive clinical diagnosis was a benign skin tumor. Total surgical extirpation was done. Histology revealed an intradermal proliferation of somewhat pleomorphic, epithelioid, spindled melanocytes in a background of desmoplastic stroma. No junctional component was present. The lesion was symmetrical and had a wedge-shaped configuration, with the base beneath the epidermis and the apex in the deep dermis. The epithelioid melanocytic population was mainly located in the superficial portion of the tumor mass and exhibited abundant cytoplasm, large vesicular nuclei with conspicuous nucleoli, and occasional intranuclear pseudoinclusions (Fig. 1). The aggregations of melanocytes diminished with the depth of the lesion, where clusters of spindled cells were dispersed among thickened and hyalinized collagen bundles (Fig. 2). Interestingly, a perineural propagation was found in the reticular dermis (Fig. 3). Proliferative activity was minimal (Ki-67 index at ca. 2\%) and mitoses were only sporadic (in "hot spots," two mitotic figures per $1 \mathrm{~mm}^{2}$ ). Immunohistochemically, the tumor cell population was diffusely positive for $\mathrm{S}-100$ protein (Fig. 4), PNL-2, and SOX-10, and only occasionally

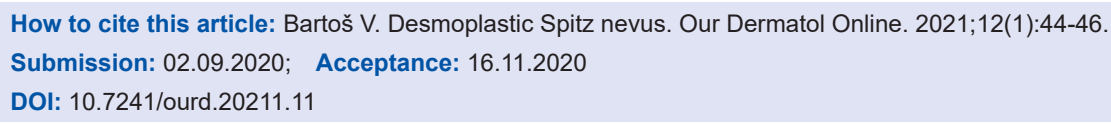




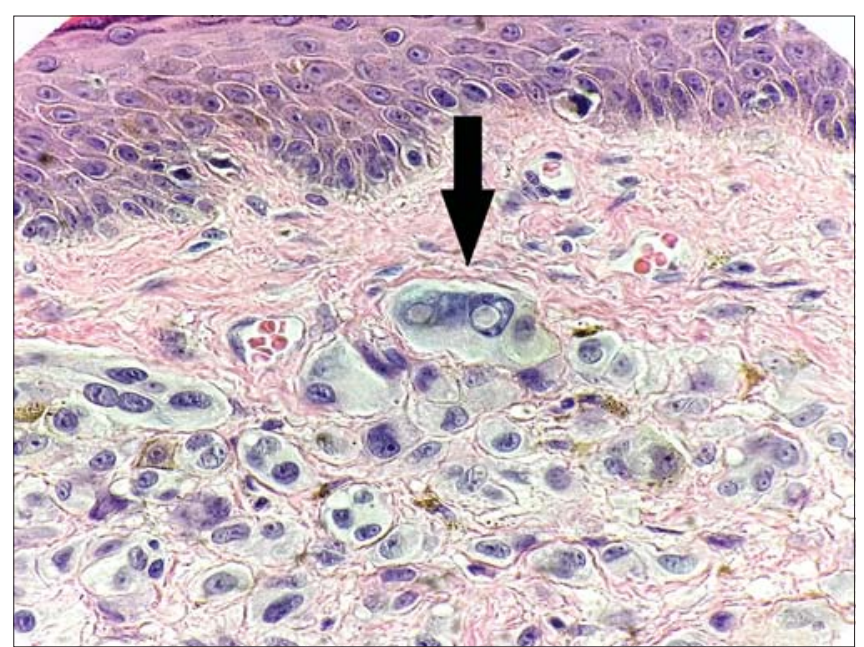

Figure 1: An epithelioid melanocytic population showing nuclear atypia with prominent nucleoli and occasional intranuclear pseudoinclusions (arrow). (H\&E, 100x).

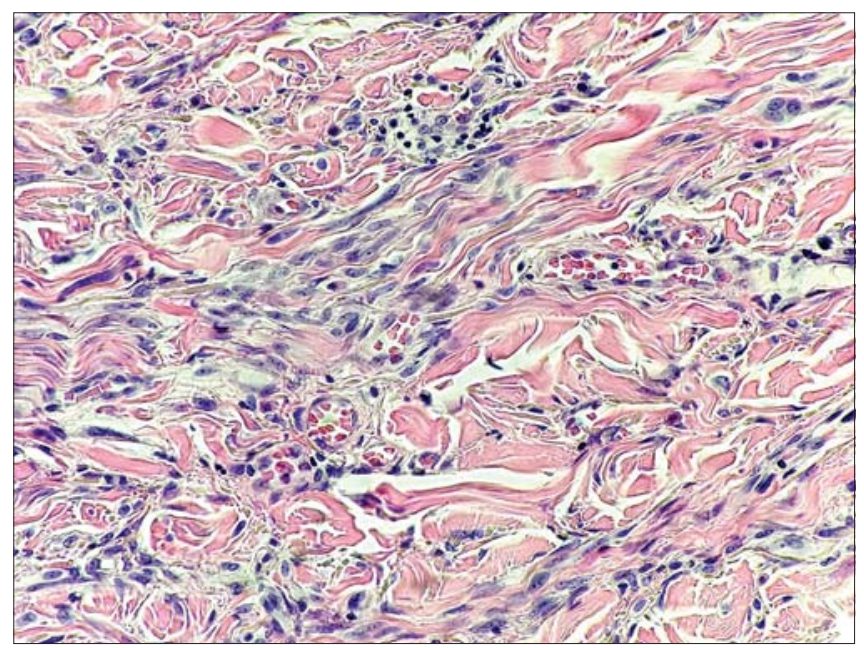

Figure 2: A spindled melanocytic population among thickened collagen bundles (H\&E, 80x).

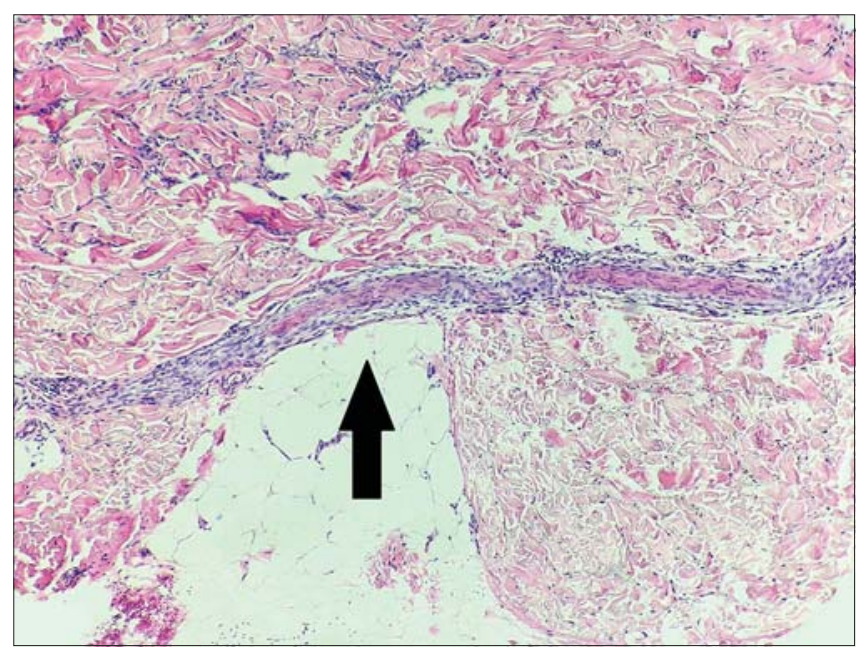

Figure 3: A perineural invasion of tumor cells (arrow) in the deep dermis (H\&E, 40x).

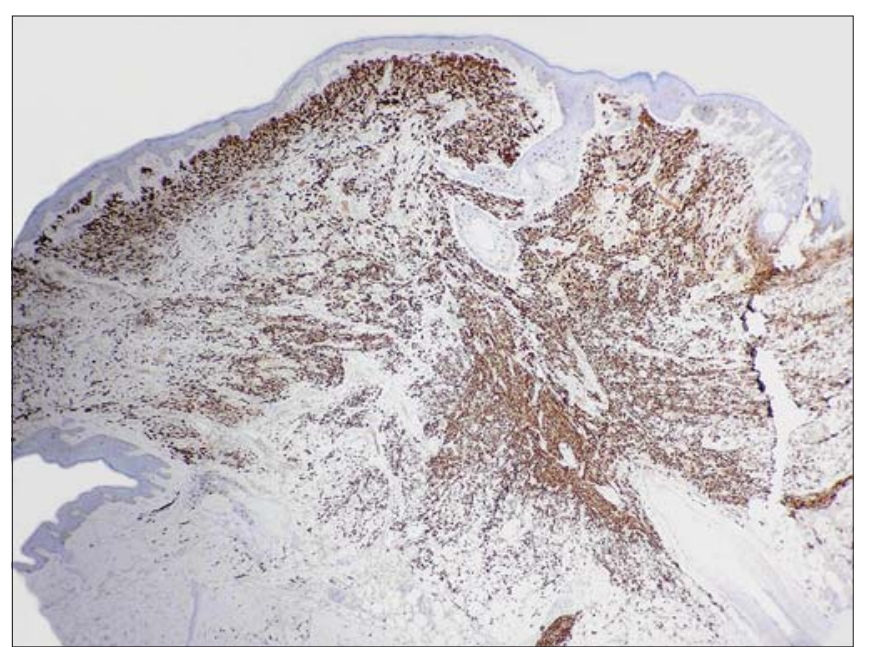

Figure 4: Diffuse immunoreactivity for S-100 protein in the tumor (10x).

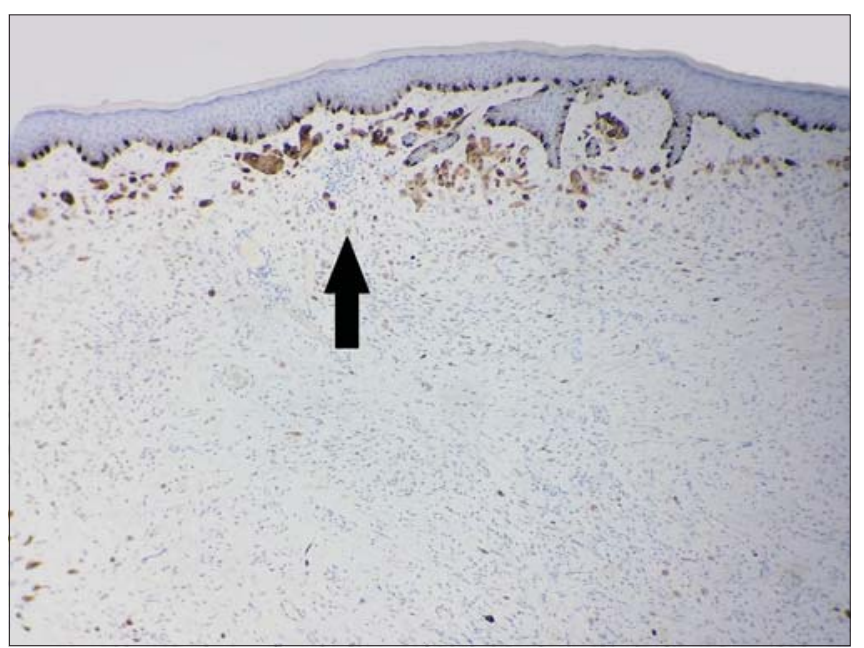

Figure 5: Focal immunoreactivity (arrow) for HMB-45 in the superficial part of the tumor $(40 x)$.

reactive for melan-A and HMB-45 (Fig. 5) in the superficial part of the lesion. Based on histomorphology and the immunophenotype, the final diagnosis of desmoplastic Spitz nevus was established. Resection margins were free of the tumor.

\section{DISCUSSION}

DSN may be a problematic diagnosis in biopsy practice. As already mentioned, it consists of somewhat pleomorphic, epithelioid, spindle-shaped melanocytes distributed among thickened, keloidal-appearing collagen fibers in the dermis [1-5]. Due to the atypia of the cells, stromal desmoplasia, and occasional neurotropism, it may be mistaken for a desmoplastic malignant melanoma (DMM) and atypical fibrous histiocytoma [1-5,7]. Because atypical fibrous histiocytoma is a benign mesenchymal tumor exhibiting a completely different 
Table 1: Summary of the clinicopathological differences between desmoplastic Spitz nevus and desmoplastic melanoma [1-5,8]

\begin{tabular}{lll}
\hline & $\begin{array}{l}\text { Desmoplastic } \\
\text { Spitz nevus }\end{array}$ & $\begin{array}{l}\text { Desmoplastic } \\
\text { melanoma }\end{array}$ \\
\hline Age & mean age of 28 yrs & $\begin{array}{l}\text { mean age of 65-75 } \\
\text { yrs }\end{array}$ \\
fexale & $\begin{array}{l}\text { male predominance } \\
\text { predominance } \\
\text { usually extremities } \\
\text { usually well- }\end{array}$ & $\begin{array}{l}\text { usually head and neck } \\
\text { poorly circumscribed }\end{array}$ \\
Circumscription & $\begin{array}{l}\text { circumscribed } \\
\text { present }\end{array}$ & $\begin{array}{l}\text { absent } \\
\text { diffusely infiltrative }\end{array}$ \\
Symmetry & wedge-shaped & may be present \\
Configuration & may be present \\
Junctional component & short and discrete & at least some long \\
Fascicles of melanocytes & present & present \\
Cytologic atypia & present & absent \\
"Spitzoid" cytomorphology & common & uncommon \\
Intranuclear & present & absent \\
pseudoinclusions & low & usually higher \\
Melanocytic maturation & absent or sporadic & may be low \\
Ki-67 index & usually absent & common \\
Mitotic activity & uncommon & common \\
Solar elastosis & may be present & common \\
Lymphocytic aggregations & uncommon \\
Perineural spreading & common & often completely \\
Adnexa involvement & at least focally & negative \\
HMB-45 and melan-A & positive & \\
\hline
\end{tabular}

immunoprofile [7], a strict distinction between DSN and DMM is much more important, as the former represents a benign melanocytic lesion, while the latter is an aggressive malignancy with a poor prognosis. Accurate diagnosis of DSN requires an experienced pathologist who will take into account a combination of clinical, microarchitectural, cytological, and immunohistochemical findings. The main clinicopathological differences between DSN and DMM are summarized in Table 1 [1-5,8]. In our patient, the findings were typical of DSN. Of note was an interesting feature: an apparent perineural spreading of the tumor cells in the deep dermis. This, at first glance worrisome, histopathological finding is generally uncommon in benign tumors. Nevertheless, in accordance with our observation, some authors [9] have even described it in benign melanocytic nevi. For this reason, it may not necessarily be considered an attribute of malignancy in atypical melanocytic lesions. In any case, this is an adverse prognostic parameter that indicates a higher risk of local recurrence.

\section{CONCLUSION}

Desmoplastic Spitz nevus is rarely encountered in dermatological practice. Although a completely benign tumor, it may result in diagnostic pitfalls. Due to its unusual histopathological features, it may be confused with a desmoplastic malignant melanoma. A knowledge of the clinicopathological differences between the two prognostically distinct skin tumor entities is essential for a differential diagnosis.

\section{Consent}

The examination of the patient was conducted according to the principles of the Declaration of Helsinki.

\section{REFERENCES}

1. Calonje JE, Brenn T, Lazar A, Billings SD (Eds). McKee's pathology of the skin: with clinical correlations. Volume two. 5th edition. Elsevier; 2020:p.1271-3.

2. Massi G, LeBoit PE. Histological diagnosis of nevi and melanoma. 2nd edition. Springer-Verlag, Berlin, Heidelberg; 2014:p.185-6.

3. Koc MK, Sudogan S, Kavala M, Kocaturk E, Büyükbabani N, Altintas S. Desmoplastic spitz naevus can be mistaken for desmoplastic malignant melanoma and dermatofibroma. Acta Derm Venereol. 2011;91:74-5.

4. Olsen SH, Patel RM, Ma L, Fullen DR. Difficulties in the diagnosis of spitzoid melanocytic lesions. Expert Rev Dermatol. 2010;5:549-60

5. Nojavan H, Cribier B, Mehregan DR. Desmoplastic Spitz nevus: a histopathological review and comparison with desmoplastic melanoma. Ann Dermatol Venereol. 2009;136:689-95.

6. Gundalli S, Kadadavar S, Singhania S, Kolekar R. Histopathological spectrum of benign melanocytic nevi-our experience in a tertiary care centre. Our Dermatol Online. 2016;7:21-5.

7. Dheenadhayalan K, Srinivasan S, Bakthavatsalam S. An unusual misleading multiple nodules on the extremities - a case report. Our Dermatol Online. 2016;7:59-61.

8. Adamicova K, Fetisovova Z, Bobrovska M, Homola I. The importance of using SOX10 for exact diagnosis of desmoplastic melanoma. Acta Medica Martiniana. 2019;19:111-6.

9. Xavier-Júnior JCC, Ocanha-Xavier JP, Camilo-Júnior DJ, et al. Interesting overlooked findings in melanocytic nevi. Surg Exp Pathol. 2019;2:19.

Copyright by Vladimír Bartoš. This is an open access article distributed under the terms of the Creative Commons Attribution License, which permits unrestricted use, distribution, and reproduction in any medium, provided the original author and source are credited.

Source of Support: Nil, Conflict of Interest: None declared. 